\title{
Thinking Bodies: The Spirit of a Latina Incarnational Imagination
}

\section{Citation}

Rivera M. 2011. "Thinking Bodies: The Spirit of a Latina Incarnational Imagination." In Decolonizing Epistemologies: Latina/o Theology and Philosophy, ed. Ada María Isasi Díaz and Eduardo Mendieta, 207-225. New York: Fordham University Press.

\section{Published Version}

doi:10.5422/fordham/9780823241354.003.0011

\section{Permanent link}

http://nrs.harvard.edu/urn-3:HUL.InstRepos:33694201

\section{Terms of Use}

This article was downloaded from Harvard University's DASH repository, and is made available under the terms and conditions applicable to Open Access Policy Articles, as set forth at http:// nrs.harvard.edu/urn-3:HUL.InstRepos:dash.current.terms-of-use\#OAP

\section{Share Your Story}

The Harvard community has made this article openly available.

Please share how this access benefits you. Submit a story.

\section{Accessibility}




\section{Thinking Bodies}

\section{The Spirit of a Latina Incarnational Imagination}

\section{Mayra Rivera Rivera}

Habla con dejo de sus mares bárbaros, con no sé qué algas y no sé qué arenas; reza oración a dios sin bulto y peso $\sim$ Gabriela Mistral, La Extranjera

Como un oleaje perpetuo, fragante, ella hace sonidos del mar. Inclinada se extiende y así suspira como si fuera una resaca delgadísima, como si fuera una palabra de ausencia.

Entonces en el lienzo del silencio y en la misma orilla del tiempo, ella se inclina toda desnuda y desnuda se mira con el rostro del agua en sus palabras.

$\sim$ Marjorie Agosín, Idiomas
She speaks in the tones of her barbaric seas With who knows what algae and what sands; She prays to god without baggage and weight $\sim$ Gabriela Mistral, The Foreigner

Like a perpetual, sweet-smelling surf, she makes sounds of the sea. Bent over, she stretches out, sighs as if she where a reed-thin tide, as if she were a word of absence. Then, on the canvas of silence and on the very shore of time, she bends over, naked, and naked regards herself with the face of water in her words. $\sim$ Marjorie Agosín, Languages

Speaking a language shaped by the sea, with the face of the water in their words, both Gabriela Mistral and Marjorie Agosín evoke in their poems geographies of a country they have left behind. Their words have traces of algae and sand, of a naked body embraced by the sea. The poets' fragrant verses have seduced me - though I tried to resist the spell of words about body and sea, alert to the dangers of bringing "body" too close to "nature." Will her body be washed away by the sea's unruly powers and be lost in its uncontrollable depth? Will she be seen as "merely" flesh, her carefully crafted words drowned in incomprehensibility, again dismissed as inadequate for theory or ineffective for politics? Her god too intimate with the turbulence of matter to be the subject of philosophy? 
Fearing being caught in the fate that awaits nature/native/body, afraid that perception of irrationality may flood the wisdom of bodies, I tried to resist the poets' enchantment. But thinking of bodies, I too conjure images of the sea.

Questions of bodies, foreign words, and fragrant seas may appear as strange openings for a discussion of epistemology, concerned as it is with discerning the proper, reliable foundations for knowledge. In Western epistemological traditions sensuality and bodies have often been considered distractions to be overcome in order to attain true knowledge. Decolonizing epistemology implies questioning the privilege of those traditions. Indeed, taking epistemology as a central concern, decolonial theorists not only explore the implications of the power structures in the production of knowledge but also seek to articulate alternative understandings and visions. Focusing on Latina body-words, this essay seeks resources to think not only beyond the legacy of colonial/imperial knowledge but also beyond its disembodied definitions of "knowledge."

In the variegated intellectual traditions that constitute Latina studies, explorations of the legacies of colonialism in the Americas commonly imply theorizations of embodiment. There are very concrete reasons for this: Colonial-sexual violence against the African and indigenous women of the Americas indelibly marked the bodies of many of their descendants. Greed, violence, and enslavement literally became incarnate. They have left "memories in the flesh" - to adapt Luce Irigaray's phrase — - and memories of the flesh seek theoretical articulation. Despite the evident dangers of being perceived yet again as one uttering barbaric words carrying who knows what algae or sand, or perhaps precisely because of the oceanic force of such speech, Latina efforts to decolonize epistemologies cannot abandon body-words.

The corporeal effects of colonial histories cannot be neatly separated into physical and cognitive elements, for the genealogical traces of colonial-sexual violence are experienced in conjunction with the materialization of social and familial arrangements also introduced by colonial power. These new structures served as tools for "the organization of relations of production, of property rights, of cosmologies and ways of knowing," all of which would have lasting effects in local and global understandings and experiences of embodiment. ${ }^{2}$

In response to the codification of bodies and the organization of humanity based on biological traits, Latina decolonial theories uncover the constructed character of body-talk in ways that would be familiar to feminists attuned to Simone de Beauvoir's celebrated statement: "One is 
not born a woman, but becomes one."3 In Latina theory, these becomings are distinctively historicized, not only in relation to patriarchy or sexual politics but also in relation to broader networks of power. It entails multidimensional deconstructions at the boundaries of identity that revolve around gender, sexuality, race, nationality, and coloniality of power. ${ }^{4}$ One might assert that Latina theories attend to the ambivalence of the identities that emerge from colonial encounters-identities that are openly and intensely sexualized, gendered, and racialized. But one would need to add that the aim is not simply to describe the configurations of power that have affected Latina bodies, but more significantly to reconfigure them by offering alternative theorizations of embodiment.

The Latina works discussed here are marked by absence and longing, troubled by past memories and present uncertainties, moved by the elusive and fleeting touch of sensuality. They even thematize their silencing, the derision of their words along with the materiality they embrace. Attempting to speak the unspeakable is for these discourses not only revealing, but also a part of becoming. ${ }^{5}$ As they are understood in these works, bodies are not simply objects of study; body-words are not merely representational, but also performative and creative. Mythology is often creatively reinterpreted, including perceptive, creative musings into the spiritual dimensions of corporeal becomings. In their creative, ecstatic moves such body-words both intersect with and unsettle Christian metaphors, inciting the present reinterpretation of spirit and flesh.

I must add a word of clarification here. The works of Chicana writers such as Cherríe Moraga and Gloria Anzaldúa are paradigmatic of the distinctive reconfigurations of the corporeal imaginary that we have come to associate more generally with Latina epistemologies. ${ }^{6} \mathrm{My}$ discussion of Latina body-words is profoundly influenced by the works of these and other Chicana writers and especially by the works of theorists who have espoused their contributions beyond the fields of literary and ethnic studies. Yet I approach those contributions with a deep awareness of the violence implied in the slippage between "Chicana" and "Latina," and of the particularities of Caribbean experiences veiled by both labels. ${ }^{7}$ The voices of Caribbean and other Latina theorists I included here therefore add important dissonance. However, I trust that the different collectivities that embrace a "Latina" stance may also embrace each other's contributions to the task of theorizing embodiment, while carefully avoiding illusions of wholeness - in definitions of our fields as much as in models of embodiment.

This essay engages a diverse group of Latina theorists to consider what they contribute to an exploration of flesh and spirit. I am suggesting that Latina theorizations of embodied becomings, what Moraga famously 
called a "theory-in-the-flesh," offer important resources for reimagining spirit. I hope these reflections will illustrate how Latina body-talk inflects spirit-talk, and how those challenges and visions may unfold in new perspectives on spirit-flesh. To discern these possibilities, I consider bodywords as they have already appeared in Latina theology and in Latina theory, and with this in mind I meditate toward the end of the essay on the incarnational spirit of those body-words.

\section{Theological Bodies}

The Argentinean theologian Marcella Althaus-Reid stands out for her consistent - and insistently transgressive - attempts to place bodies at the center of theology. She grounds her theology of the body in a basic tenet of liberation theology, namely that "Latin American liberation theology is based on the search for the materiality of transcendence." That search leads liberation theologies to people's stories, to everyday experiences, "because they reveal the falsity of the border limits between the material and divine dimensions of our lives."

In U.S. Latina/o theology, this interest in the deconstruction of the rigid boundaries between materiality and divinity is evidenced in the privilege it has given to popular religiosity. As Roberto Goizueta describes it, Latina/o popular Catholicism recovers a medieval appreciation for a creation infused with divine presence. This was a faith "firmly anchored in the body: the body of the cosmos, the body of persons, the Body of Christ." That worldview was almost lost both in the Reformation attacks against images and saints and in Catholic responses to such attacks, but its traces are still visible in "the faith of Hispanic people" which is "primarily embodied and expressed in and through symbol and ritual." interpretations of these religious practices, Latina/o theologians have emphasized the sacred elements in materiality and physicality, especially in the context of ritual practices.

More direct explorations of the body appear in Latina/o theologians' discussions of mestizaje/mulatez, which Ada María Isasi-Díaz identifies as "the locus theologicus" of her work. ${ }^{11}$ In colonial contexts, mestizaje/mulatez were pejorative terms for those of "mixed blood," but they have now been reclaimed and redefined by Latina/o thinkers as a way of bringing together cultural, historical, and corporeal aspects of identity. Mestizaje/mulatez is, in Isasi-Díaz's words, "the Hispanic/Latino incarnation of hybridity and diversity." Latina/o theologians have used the concepts of mestizaje/mulatez to 
elucidate "the abstruse evocations of rejection, pain, and spiritual searching" as well as the redemptive potential that they hold for self and society. ${ }^{13}$ These discussions about mestizaje/mulatez are part of Latina theology's body-talk, and their broader implications for constructive theology continue to be debated and developed.

Latina/o theologians' attention to popular religiosity and embodied identities is consistent with liberation theology's commitment to foreground the concrete experiences and material struggles of marginalized people: the of the poor and the disappeared, of those in pain and hungry, of those persecuted and tortured. What Althaus-Reid calls a "theology of the spiritually concrete and the materially spiritual" 14 is an attempt to reclaim and extend that liberationist pledge, for the bodies in Latin American liberation theology ended up being too neatly organized, too readily sorted according to accepted political and theological categories, Althaus-Reid contends. ${ }^{15}$ In that neat and "decent" organization, liberation theology neglected rebellious, unruly, queer bodies. Furthermore, in the interest of concrete representations, these theologies lost a certain ghostliness that is also part of embodied life: the unseen, the ungraspable, and the no-longerliving in and among us. ${ }^{16}$

Althaus-Reid's work seeks to move beyond these tendencies of orderliness by attending to common objects - not only in devotional contexts - and to rejected, disruptive bodies. She does not shy away from disorder. Althaus-Reid's texts are populated with unruly bodies and body parts: Dirty feet are carefully observed in "Feetishism," and numerous sexual organs are (perhaps fetishistically?) presented throughout Indecent Theology. ${ }^{17}$ These intensely carnal images coexist in her writings with other ghostly presences: rebellious corpses that refuse to disappear and poor, displaced people who haunt the living cities only in the shadows of the night - as fleeting presences. ${ }^{18}$ Their appearances disturb the boundaries of corporeality.

The challenge to the myth of the stable, whole body performed through the irruption of multiple and incomplete bodies into theological discourses should be read, I think, alongside other attempts by Latina theorists to subvert "the founding myth of original wholeness, with its inescapable apocalypse of final return to a deathly oneness"- as Chela Sandoval describes it. ${ }^{19}$ This is an unavoidable step toward disrupting the myth of the unchangeable wholeness of truth. To seek what María Pilar Aquino calls "an evolving-becoming truth" 20 entails the interrogation of the image of a self-present God, whose simple oneness depends on remaining unaffected by multiple, changing bodies. Given the power of the impassible, unchanging God in Christian imaginaries, incomplete and incoherent bodies may seem strange places to search for the materiality of 
transcendence - or for transcendence in materiality. But this strangeness points to a key aspect of this project: a rethinking of divine transcendence that does not presuppose completeness or absolute separation, one that is more amenable to the flux and disruptions of the flesh.

Whereas Althaus-Reid's body images hardly add up to an organized, whole, unified body - or to a coherent theory of embodiment - they do produce aesthetic effects that are theologically significant. These effects may be similar to what Patricia Cox Miller describes, in her reading of hagiographic texts, as "visceral seeing." ${ }^{21}$ Miller explores "narrative pictorial strategies" that draw readers "into the images by virtue of their very bodies." ${ }^{, 2}$ Displaying "ambiguous corporealities"- bodies that are both ephemeral and tangible, both fragmented and whole - such texts "induced a stance for the beholder to occupy, a stance in which the senses had cognitive status and in which the intellect was materially engaged."23 Miller argues that such sensory realism is aimed at teaching "the reader how to see that the everyday life is saturated with the palpable" presence of the holy. ${ }^{24}$ Similarly, by displaying starkly carnal images and ambiguous corporealities, Althaus-Reid's texts seem to aim at inciting visceral reactions in their readers and challenging the assumed boundaries between the sociopolitical, corporeal, and spiritual.

However, Althaus-Reid's shocking rhetorical strategies often threaten to reinscribe the all-too-familiar stereotypes of the hypersexual Latina - a problem that needs more careful attention. If coloniality of power produces not one but two or maybe more different gender systems for colonizing and colonized subjects, as María Lugones has persuasively argued, Latina critiques need to address the differences in constructions of gender and sexuality across the colonial divide. ${ }^{25}$ That is, they need not only challenge Victorian gender images by, for instance, reclaiming the spiritual dimensions of eroticism, as Althaus-Reid does. They must also address the intense sexualization of women on the other side of the colonial divide: what Lugones calls the "dark side" of the gender system, that is, the gender structures imposed on the colonized.

Given this tendency of theological discourses either to ignore real bodies altogether or to idealize their beauty and their capacity for pleasure, Althaus-Reid's work is a welcome provocation. ${ }^{26}$ Turning that provocation into a theoretical critique that attends to the resistance of bodies to rigid ordering systems and recognizes even the "untouchable" bodies of society ${ }^{27}$ entails first a closer look at the paradoxes of embodiment. For that analysis I now turn to works in Latina studies (outside of theological fields), and in so doing I return to the sea. 


\section{Disruptive Bodies}

The Puertorrican poet Luz María Umpierre links her critique of the dominant ordering of bodies to a well-known symbol of the island: the walls of the city of San Juan. ${ }^{28}$ Built to protect the city against foreign invasion during the Spanish colonial period, the old walls are today proudly displayed in souvenirs and tourism propaganda. That a fortified city may signify Puertorrican identity provokes Umpierre, who sees in it an appropriate symbol of the traps of the closed ideals of national identity and its compulsory heteronormativity. The walls of the city lock bodies in restrictive scripts; the walls of the city isolate the island from the sea. To allow for the needed contact between island and sea, Umpierre calls for words: "for the sea to come / to touch that island's land / one needs / your words. ${ }^{, 29}$ These words are needed not to impose order on the unruly sea, but to liberate the sea from the wall. These are not the seemingly disembodied words commonly associated with creation myths; this is not a version of logocentrism. These are body-words that emerge from the islanders' bodies, from their mouths, stomachs, esophaguses, and so forth. Body-words contain for the poet the force that can erode the oppressive walls of nationalism and heteronormativity and expose identities to the touch of the sea-the watery medium of connection between shores and an agent of continual change. ${ }^{30}$

The effects of colonial history and nationalism on the bodies of the island and its subjects, to which Umpierre alludes, are not unrelated to the effects of racial ideologies in Latina bodies. For even when focusing mainly on the corporeal experiences that take place in the continental United States, Latina discourses generally stay in touch with the movements between shores and across borderlands that mark and shape peoples' bodies. ${ }^{31}$ Standing between shores, in literal or figurative "exile," such bodies are often also in "sexile." As in Umpierre's poem, Latina bodywords seek to erode the confining structures of U.S. national, racial, and sexual ideologies.

The structures that constrain and regulate identities function in part through appeals to the body that naturalize social constructions. Yet the boundaries between discursive claims and bodily experience are hardly impermeable. Bodies are formed and deformed as they are read in their social contexts, as they are touched by others. Those who are stigmatized often experience being caught in the dominant gaze, which affects the developments of their "bodily schema," as Fanon would put it. ${ }^{32}$ The wounds produced by the seemingly disembodied gaze are felt viscerally, but their meanings might remain inscrutable. Such experiences are often 
characterized by a deep sense of uncertainty: Those who are subject to an objectifying gaze are unable to fully decipher just what the observed body signifies to the observer. Against the expectations of certainty produced by the naturalization of corporeal markers of identity, Latina/o body-talk often foregrounds - even dramatizes - puzzlement. The meaning of his own skin color is Richard Rodriguez's recurrent question in Brown. ${ }^{33}$ Rodriguez ponders how the import of his brown skin shifts as he moves between worlds: the world of white Americans, where he "felt least certain about the meaning of [his] brown skin"; the racially diverse world of the early civil rights movement, where he felt "as safe as [he] ever felt"; the later world of clearly demarcated identities, where he no longer felt at home in the gatherings of ethnic groups other than his own. Brownness, he concludes, is not only an unstable sign; it is also an elusive one that simultaneously invites and resists being deciphered. ${ }^{34}$

The uncertainties of corporeal identity affect not only public interactions like the ones just described, but also intimate familiar relations. Pained by the awareness that her own light skin has given her privileges that are denied to her own mother, Moraga calls attention to the unreliable grounds of social identification.

See this face?

Wearing it like an accident

Of birth

It was a scar sealing up

A woman ... ${ }^{35}$

Thus Moraga describes her experience of having her body read in the United States: a complex heritage reduced to the visible: a face, a sign, a scar. As Martín Alcoff observes, although "structural power relations ... [determine] the meanings of our identities ... the focal point of power most often operates precisely through the very personal sphere of our visible social identities. ${ }^{" 36}$ The fissures of a racially divided social body fracture families along the differences in visible traits of their members. Even when those differences are the random outcome of genetic chance, they acquire added weight as signs of "the real" and thus as perceived evidence for social classification.

Visible corporeal traits become social data; social classifications become bodily wounds. Thus, the critical power of body-words stems from their ability, on the one hand, to resist the reduction of the body to biological inheritance and, on the other hand, avoid the illusion of freedom to choose social affiliations unencumbered by the body and its history. Indeed, by highlighting the effects on her most intimate relationships of her 
corporeal entanglements with oppressive value systems, Moraga avoids such illusions of absolute freedom. Skin for Moraga is not only a mark of her ancestry, but also and simultaneously its mask. It is an accident and a scar that separates her from her mother-and unites her with her oppressor. Although a lighter skin can easily lead to participation in a system of clearly demarcated fields of power, it is often also a source of estrangement. This estrangement can be felt viscerally, for as she says, "The object of oppression is not only someone outside my skin, but the someone inside my skin." ${ }^{, 37}$ The tension is inescapable. "Both strains [the conquistador and the native] contributed to their bodies, to their waking spirits," Rodriguez writes, as he draws the crucial implication:

"Righteousness should not come easily to any of us." 38

Locating the subject in relation to the native/conquistador dyad, however, obliterates the African influence that is essential for the Caribbean body imaginary, a problem that Isasi-Díaz has tried to address by insisting that we link mestizaje to the term mulatez. The simple dyadic structure native/conquistador may also, and more problematically, lead to construing identity as biological inheritance made up of the mixture of discrete substances. A theorization of embodiment needs to challenge such reductive understandings of inheritance. Yet, as an epistemological critique, allusions to the native/African/conquistador elements exemplify the multiplicity of relationships that constitute a body-incorporating the familiar and the unknown, the visible and the invisible, the nurturing and the oppressive. Attending to that multiplicity contributes to the disruption of myths of homogeneous subjectivity and unambiguous identification.

It is not only the complexity and irreducible multiplicity of biological inheritance that we must assert; we also need to scrutinize the analytical categories used for such work. Such a critique is implicit in Gloria Anzaldúa's question: "Just what did she inherit from her ancestors? . .. [W] hich is the baggage from the Indian mother, which is the baggage from the Spanish father?" 39 Highlighting the implications of differentiating between race, ethnicity, and social ideology, Anzaldúa adds, "Pero es difícil differentiating between lo heredado, lo adquirido, lo impuesto." uncertainties of heritage are clearly irreducible. ${ }^{41}$ In contrast to the apparent clarity and stability of the theoretical categories that are used to describe it, self-identity is conflictive and puzzling, and its articulations should resist the illusions of epistemological certainty. Highlighting the perplexity of their own attempts at self-representation, Latina body-words may call into question the compartmentalization of identity produced by the naturalization of categories of analysis, not by ignoring the body, but by bringing theory closer to the flesh. 
The apparent celebration of the racial impurity associated with Latina theories is best understood in conjunction with its critique of, and invitation to move beyond, the illusion of purity in U.S. culture. At the heart of U.S. culture's privilege of purity, Rodriguez observes, is a repression of a male erotic fantasy and an enforced silence around the history of race in the United States. "When mulatto was the issue of white male desire, mulatto was unspoken, invisible, impossible." ${ }^{42}$ And brown bodies may be seen as icons of terrifying, unnamed desires of the American symbolic. Rodriguez's goal is to turn that anxiety into a provocation that may lead to a deeper questioning of the very foundations of U.S. racial ideology. He turns brown into a category of analysis. "Brown made Americans mindful of tunnels within their bodies, about which they did not speak; about their ties to one another, about which they did not speak. This undermining brown motif, the erotic tunnel, was the private history and making of America." ${ }^{, 43}$ The return of such suppressed knowledge, appearing in a story or body, produces violent anxiety. ${ }^{44}$

The challenge to acknowledge, perhaps even embrace, impurity entails for Rodriguez an epistemological shift to recognize "the ability of language to express two or several things at once, the ability of bodies to experience two or several things at once." ${ }^{.45}$ And this affirmation of multiplicity is a sexual challenge too. We observed that in Moraga's work a woman's skin appears as the site of memories of the touch of the maternal connection as well as of painful and guilt-ridden separation from her brown mother. However, despite her light skin, heterosexual ideologies "darken" her; because she desires women, Moraga considers her sex "brown." ${ }^{, 46} \mathrm{~A}$ body acquires contrasting meanings in relation to different axes of power: Visible traits clash with familiar and biological bonds; sexual desires disturb ethnic affiliations, and so on. The disparate social meanings projected onto a body unavoidably mark it with incongruent desires and irreducible tensions, though never completely or unilaterally. The contradictory effects that different ideologies have on a body do not entail a simple internalization of social differences. Espousing subjectivities where "the individual is herself seen as 'fragmented' and 'contradictory,' $<$ HS $>$ " does not entail "displacing attention from the distinctions that exist between" bodies, Paula Moya asserts. ${ }^{47}$ Instead, the goal here is to trace how the rifts that divide collectivities from one another, fragmenting the social body, materialize in unique but complex forms of embodiment-and in their transfigurations.

Corporeal pain, difficulty, and failure are undeniable effects of patterns of social discrimination, but their articulation cannot be reduced to expressions of victimhood or fatalism. If bodies have the ability to experience several things at once, they can also hold together pain and joy, 
failure and hope - and creatively transform those experiences. Whereas Yvonne Yarbro-Bejerano characterizes Moraga's depictions of identity as "non-redemptive," ${ }^{48}$ I read in such refusals to resolve the tensions of sociocorporeal existence glimpses of an open-ended view of salvation. In this model, redemption is never accomplished once and for all: It takes place in the transient, finite events of our lives and in the midst of the ambiguities and potentialities of our social relations. Exposing social structures and practices that inhibit corporeal flourishing reveals possibilities for unsettling them, thus opening spaces where new relationships may emerge. Yet the envisioned end is not the elimination of the tensions of corporeality in order to produce a coherent, whole body. Such an ideal would reinscribe what we referred to before as "the founding myth of original wholeness, with its inescapable apocalypse of final return to a deathly oneness, ${ }^{, 49}$ that in effect covers up multiplicity under ideologies of purity or homogeneity. Instead, we are seeking visions of redemption in which bodies become capable of embracing their multiplicity without having to become one.

A creative articulation of such longing for the transfiguration of bodily experience is represented in the song titled "Raza Pura" (Pure Race). The context is not the U.S. "mainland," but Puerto Rico. Based on the first verses of the song - "I am of a pure race / pure and rebellious"the song may seem to espouse a problematic celebration of racial purity. But as the song proceeds to describe the conflict and violence that marks the subject's history, it demonstrates the impossibility of any simplistic acceptance of that ideal of purity. Indeed, the song displaces the logic of purity through parodic repetition. The claims to a "pure race" are immediately followed by a first-person description of its wounded body: "I am of a pure race which has had nails in its hands / and scars on its knees." The implicit links between Jesus' crucifixion and slavery lead to a redefinition of the claimed "purity": "I am Borincano / black and gypsy / I am taíno." Clearly and defiantly, the song affirms the irreducible multiplicity of the narrator's genealogy. But it simultaneously constitutes its complex corporeal history as the basis for a strange purity defined not by assumed biological homogeneity, but in relation to struggle, survival, and transformation. "I am tears and also pain / for all that I've lived / for all that I've suffered / I am of a pure race / pure and rebellious." While foregrounding experiences of violence and pain, the subject is not depicted as an object defined by victimization, but rather an active agent who makes "song with the chains," "escaping from the whip / and stealing magic from death." The body appears as the site of historical conflict and oppression as well as the source of mysterious, creative powers for resisting, challenging, and transgressing the logic, the "knowledge," that supports her 
subordination. The memory of an incarnate past and the articulation of improbable hopes combine - even in song - to effect the materialization of a new self.

In these transformative visions, bodies do not leave behind their memories of pain and loss; nor do they dream of attaining absolute freedom from social constraints in such a way that bodies could re-create themselves independently of others. At its most fundamental level, bodies are constituted, understood, and experienced in relation to others - not only to those others under whose gaze we feel the power of social controls but also those familiar bodies among which we first learned to see ourselves as individuals. Physically and cognitively, bodies are shaped by other bodies and through them they are marked by their meanings in society. Those processes are fraught with uncertainty, yet they are also dynamic and open to transformation through performative interventions: the ritual practices of popular religiosity, artistic creations, social activism, critical writing. Those performative interventions are inherently relational: emerging from and limited by social and familiar bonds, lured and empowered by the movements of the spirit in the flesh.

\title{
Spirit-Flesh
}

\begin{abstract}
The ceremony always begins for me in the same way ... always the hungry woman. Always the place of disquiet moves the writing to become a kind of excavation, an earth-dig of the spirit found through the body. The impulse to write may begin in the dream, the déjà-vu, a few words, which once uttered through my own mouth or through the mouth of another, refuse to leave the body of the heart.
\end{abstract}

Cherríe Moraga

The body-words presented in the previous sections emerge from places of disquiet. Uneasiness, tremors, and desire give impulse to hungry searches and distinctive modes of writing. Latina body-words attempt to articulate not only the historical and social determinations of corporeality but also that which exceeds representation and yet gives impulse to speaking and writing: the body's unruly materiality, its mysterious spirituality. Such modes of writing invite an explicitly theological reading. The aim of this reading is not to Christianize Latina theoretical contributions by subsuming them under doctrinal language. Instead I seek to allow Christian discourses to be affected, to be disturbed yet again, by accounts of the movements of the spirit found through the bodies of those it has often ignored. ${ }^{50}$ 
A discussion of "the spirit found through the body," of spirit in the flesh, can hardly avoid engaging the ancient insights of the "incarnation": that central teaching of God in carne. The earliest authorities of the Christian tradition declared it a heresy to undermine the startling affirmation of divinity in the flesh. But theology all too often moves in the opposite direction - turning away from the realm of unruly earthy bodies. In its dogmatic formulations, the incarnation tends to be safely contained within Jesus' skin or reconceived in highly abstract, metaphysical terms that in effect distance the incarnation from our ordinary bodies: from the everyday experiences of working and dancing, praying and protesting, making bread and making love.

To take Latina theory as a starting point for an incarnational imagination, as I am suggesting here, is already to resist the tendency to circumscribe the incarnation to one body or to a one-time event that proves the rule of an otherwise disembodied deity. It is to affirm with Ivone Gebara that "the incarnation, the presence of the greatest of mysteries in our flesh, is more than Jesus of Nazareth." ${ }^{.51}$ Rather than setting the incarnation in opposition to our carnality, this reading seeks to embrace the incarnation's unfettered bond to our flesh. Attending to the spirit in the flesh of rejected, disorderly bodies is hardly to dismiss Jesus' body. Instead we read his body - a material, finite, stigmatized, vulnerable body - as revealing the scandal of divinity in the flesh, or more accurately, of the divine becoming flesh. We take ever more seriously the transformative power of a singular person, a unique history, the significance of the wounds that mark even a glorified body.

An interpretation of the incarnation as "the greatest of mysteries in our flesh" implies, methodologically, openness to learn from real, finite bodies, to seek the wisdom of body-words and their transformative power. This in turn entails a challenge to entrenched assumptions about the orientation of spiritual pursuits. The mind/body, spirit/matter dualisms pervasive in Western epistemologies lead to depictions of human development (and knowledge) as movements away from bodily "instincts" toward "rational thought," away from flesh/nature/mother toward culture conceived as the realm of the "free spirit." This reign of culture, it is well known, has been consistently associated with the agency of men/fathers, specifically of those who, by occluding their own dependence on the physical labor of women and disenfranchised men, may entertain the fantasy of life unencumbered by materiality or relationships. Reason and culture are thus imagined as rising above bodies and matter. Standard depictions of spiritual development assume the same path. Christian theologians and mystics commonly describe spiritual growth as ascension toward the airy heavens. In contrast, I am intentionally adopting Moraga's 
depiction of the spiritual pursuit as a movement of excavation or an earthdig - a movement that takes us deeper into our fleshliness.

Through my reading of the Latina theorizations of corporeality, I have sought to foreground the dynamic and relational nature of such fleshliness. The challenges to the myths of original wholeness, homogeneous subjectivity, unambiguous identification, the illusions of purity and visual certainties, for instance, attempt to open up spaces for a complexly political model of carnality. In that view, bodies are always becoming through processes of identification and differentiation, objectification and transgression, fragmentation and transmutation. A theology-in-the-flesh also complicates and implicates the divine in these corporeal processes - the materialization of social relations, the enfleshment of the past in genes and memories, the transfiguration of corporeal wounds and social relations.

The intricate constitution of bodies that are simultaneously social, material, and spiritual would be undermined by conceptions of the spirit as a simple being or as a force that aims at permanent completion and wholeness - views that betray an epistemological privilege of oneness over plurality. The spirit that I am invoking here is not imagined as an alien element added to earthy objects. It is not an external container, a teleological goal, or an archetypal form that would gather the complexity of flesh into a unified whole. The spirit is that intrinsic part of the flesh. To emphasize the continuity between material and spiritual dimensions of embodiment I use the term "spirit-flesh." Just as "body-words" names discourses grounded on the continuity between corporeality and language, "spirit-flesh" emphasizes the inseparability of these concepts. In "spiritflesh," the hyphen marks a boundary of distinction that does not tend to separation. Spirit and flesh flow into one another, each transfigures the other. The boundary between them remains as elusive as it is vital. ${ }^{52}$

Spirit-flesh is the substance of corporeality - its matter and energywhich is shaped by, but may also unsettle, layers of social and historical inscription and may disrupt old patterns of materialization. Yet, the living energy of the spirit-flesh does not eliminate the ambiguities of bodies that are ephemeral and tangible, fragmented and manifold, neither whole nor deficient. Thus the spirit is not to be associated with triumphalism or ideologies of absolute purity or perfection. Pain, difficulty, and failure are not antithetical to the movements of the spirit-flesh, for it is not independent of sociocorporeal life. In the transient events of finite, vulnerable existence, the spirit-flesh makes possible the transfiguration of our wounds and the incarnation of improbable hopes. This is the spirit, not of simple belongings, but of hybrid becomings. 
The common depictions of spirit as primordially immaterial are challenged by these affirmations of spirit-flesh as constitutive of our bodies, while recognizing the spirit also in the nonhuman elements on which life depends. The biblical images of spirit as fire, water, and wind capture the material qualities of its life-sustaining energies, as well as its fluid and transforming power. We can recover the dynamic materiality of these images of the spirit as part of the work of countering received traditions that dismiss the epistemic import of materiality. These elemental images - like those of sea, algae, and sand identified in this essay's opening poems - may also help us reclaim the importance of the nonhuman elements in shaping of our corporeality. Regarding ourselves "with the face of water in [our] words" is to begin to erode the anthropocentrism of modern cosmologies and their ideologies of dominance.

The spirit-flesh is never simply our own; it can never be fully contained within the boundaries of the self. In contrast to atomistic views of embodiment, this reading asserts that our bodies are irreducibly linked to the nonhuman elements that sustain life; the marks of savage seas are sometimes legible in our body-words. Our bodies are shaped by some others whom we see and touch, as well as by those we perceive only as ghostly presences. ${ }^{53}$ Earlier I referred to Althaus-Reid's allusions to the ghostly as a way to bring to our attention the traces of the no-longer-living in our selves, to the unseen presences of the excluded ones, as well as to the indeterminate aspects of bodily identity. Forgotten histories, suppressed knowledge, and ignored relationships do return, but they do not always appear with the weight of certainty that accompanies "reasonable" facts that can be observed from a safe distance. Instead they are experienced as fleeting insights or disquieting tremors in our bodies. We cannot be certain about just what we inherited from our ancestors - "which is the baggage from the Indian mother, which is the baggage from the Spanish father," which is the baggage from the African parents? We cannot clearly differentiate "between lo heredado, lo adquirido, lo impuesto." ${ }^{54}$ Yet we know that the past is not simply superseded by the present, the ancestors are not merely outside our skin. Certain elements of the past and some aspects of the bodies of others are inherent in our own; as ghostly presences they remind us of our elusive, intimate connections with them.

Ghostly presences remind us that the spirit-flesh is never ahistorical, even if it lures us beyond what has been. The longings and courage to articulate hidden memories of the flesh are also associated with the movements of the spirit. Indeed, encounters with the past are sometimes represented as the presence of the spirits. Although modern Christianity has not been generally hospitable to talk of spirits from the past and has attempted to clearly differentiate the Holy Ghost from all other ghosts, we 
do find an image of the spirit as facilitator of memory in the Gospel of John. In that gospel's narrative, the spirit that was in Jesus infuses his followers and witnesses after his death. Tellingly, the spirit comes to them from the stigmatized body of a man who had been executed, a spectral body now able to walk through walls and yet still visibly wounded, still bearing the marks of violence on his flesh. How can this image not remind us of the ghostly appearances that populate the pages of the narratives of oppressed communities? The spirit that Jesus breathes into his followers is aptly called the spirit of truth, for it will remind the emerging community what they learned and experienced; it will also help them understand the baffling events of their past. The Johannine spirit is thus divine presence in remembrance - indeed, the very possibility of relating to the past. Latinatheory's commitment to remember may resonate with the image of a spirit of remembrance as a spirit of truth. It may imagine the spirit enlivening memories in our flesh, inspiring attunement to their concreteness and their fluidity, while acknowledging in humility the irreducible uncertainties of remembrance.

The spectral elements, disconcerting as they may be, are not opposed to the body: They represent the fluent, fluid, dispersive aspects of flesh, of subjects that defy objectification. Ancestral memories haunt our present experiences, yet these do not exhaust the spectral elements of embodiment. A kind of ghostliness haunts even the most concrete characterizations, pointing beyond the represented to that which eludes representation, that for which we don't have concepts or words, that which unsettles established rationality and resists closure.

"I perceived a language of the ephemeral, the unseen, and the halfpresent that expressed the spiritual as a reference either to the divine or to that which is socially ghostly - certain bodies, desires, cultures, even locations. In this sense, the artwork itself was altar-like." ${ }^{, 55}$ Thus Laura Pérez describes her analysis of Chicana art. ${ }^{56}$ By depicting the unrepresented and unrepresentable elements in the spiritual and social realms, such artistic works invite us to explore corporeal mystery in nonreductive ways. "Spirit works," as Pérez aptly calls them, do not simply uncover suppressed knowledge, they "teach us to perceive and imagine differently." effect of ignorance or mystification. For in our dark or light skins, in our visible and invisible traits, in our unruly desires and sensitive wounds, the mysterious powers of spirit-flesh enable the materialization of unforeseeable possibilities.

This vision of spirit-flesh strives to maintain the balance between an awareness of vulnerability and a defiant trust in life. Refusing to leave behind the body of the heart or the memories of our flesh, we trust the 
energies of spirit-flesh. Such a trust differs from the sense of security found behind a fortified wall. Instead it is the kind of trust found by those who expose themselves to the connecting, transforming touch of the sea.

Turning what we have been toward what we may yet become, a Latina image of spirit-flesh reclaims the wisdom of bodies to re-envision "salvations" that do not abandon corporeality, finitude, or its wounds. By uttering words impregnated with traces of sand and sea, Latina thought may keep drawing epistemology and body closer, as it brings forth incarnate words. 


\section{Thinking Bodies, by Mayra Rivera Rivera}

The first epigraph is from Margot Arce de Vazquez, Gabriela Mistral: The Poet and Her Work, trans. Helene Masslo Anderson (New York: New York University Press, 1964); trans. modified. The second epigraph is from Sargaso, trans. Cola Franzen (Fredonia, N.Y.: White Pine Press, 1993), p. 28 (Spanish), p. 29 (English); trans. modified.

${ }^{1}$ Luce Irigaray, An Ethics of Sexual Difference, translated by Carolyn Burke and Gillian C. Gill (1984; Ithaca, NY: Cornell University Press, 1993), 191.

${ }^{2}$ María Lugones, "Heterosexualism and the Colonial/Moderm Gender System," Hypatia 22, no. 1 (2007): 186.

${ }^{3}$ Simone De Beauvoir, The Second Sex, trans. H. M. Parshley (New York: Alfred A. Knopf, 1953), 281.

4 "Coloniality of power" is a term used by Lugones, Anibal Quijano, and others to denote the system that "introduces the basic and universal social classification of the population of the planet in terms of the idea of race..... $<$ HS $>$ " Lugones, "Heterosexualism and the Colonial/Modern Gender System," 190.

${ }^{5}$ Nancy Raquel Mirabal argues that these discourses acknowledge that "expressing the inexpressible and speaking the unspeakable are often part of the becoming, of the revealing, inherent in knowledge production" (Introduction to Technofuturos: Critical Interventions in Latina/o Studies, ed. Nancy Raquel Mirabal and Agustín Laó-Montes (Lanham, Md.: Lexington Books, 2007), 19.

${ }^{6}$ Lázaro Lima, The Latino Body: Crisis Identities in American Literary and Cultural Memory (New York: New York University, 2007), 129. Lázaro Lima argues that Anzaldúa and Moraga reconfigure "citizenship as a gendered, racialized, and desiring mobile imaginary written on the body" (129).

${ }^{7}$ On the problematics of the homogenization of the representations of "Latina/o" experience in theology, specifically the creation of "a mexicanized construction of Latino/a identity" (12), see Michelle Gonzalez, Afro-Cuban Theology: Religion, Race, Culture, and Identity (Gainesville: University Press of Florida, 2006), especially 15-33.

${ }^{8}$ Marcella Althaus-Reid, Indecent Theology: Theological Perversions in Sex, Gender, and Politics (New York: Routledge, 2000), 148.

${ }^{9}$ Roberto Goizueta, "The Symbolic Realism of U.S. Latino/s Popular Catholicism," Theological Studies 65:2 (June 2004): 263.

${ }^{10}$ Ibid., 262.

${ }^{11}$ Ada María Isasi-Díaz, Mujerista Theology: A Theology for the Twenty-First Century (Maryknoll, N.Y.: Orbis Books, 1996), 64.

${ }^{12}$ Ada María Isasi-Díaz, La Lucha Continues: Mujerista Theology (Maryknoll, N.Y.: Orbis Books, 2004), 159. 
${ }^{13}$ Benjamin Valentin, Mapping Public Theology: Beyond Culture, Identity, and Difference (New York: Trinity Press, 2002), 53. For an overview of Latino/a theologians' contributions and debates on the subject of mestizaje/mulatez see also Gonzalez, AfroCuban Theology, 21-29.

${ }^{14}$ Marcella Althaus-Reid, "Feetishism: The Scent of a Latin American Body Theology," in Toward a Theology of Eros: Transfiguring Passion at the Limit of Discipline, 134-152, ed. Virginia Burrus and Catherine Keller (NY: Fordham University, 2006), 137.

${ }^{15}$ Ibid., $144-45$. OK as is

${ }^{16}$ Ibid.

${ }^{17}$ Althaus-Reid, "Feetishism," and Indecent Theology.

${ }^{18}$ Marcella Althaus-Reid, "El Tocado (Le Toucher) : Sexual Irregularities in the Translation of God (the Word) in Jesus," in Derrida and Religion: Other Testaments, ed. Yvonne Sherwood and Kevin Hart (New York: Routledge, 2004), 393-406. As discussed later in this essay, Laura Pérez finds in Chicana art a similar emphasis on the ghostly in the midst of the concrete, as that which expresses both the spiritual and the socially ephemeral elements of life (Laura E. Pérez, Chicana Art: The Politics of Spiritual and Aesthetic Altarities [Durham, N.C.: Duke University Press, 2007]).

${ }^{19}$ Donna Haraway, cited in Chela Sandoval, Methodology of the Oppressed (Minneapolis: University of Minnesota Press, 2000), 171.

${ }^{20}$ María Pilar Aquino, "Latina Feminist Theology: Central Features," in $A$ Reader in Latina Feminist Theology: Religion and Justice, ed. María Pilar Aquino, Daisy L. Machado, and Jeanette Rodriguez (Austin: University of Texas Press, 2002), 150.

${ }^{21}$ Hagiography is also Suzanne Bost's description of Chicanas' approach to history. She proposes that "hagiography" "is a more appropriate term for the ways in which these writers use the past, since it focuses on mystical bodies and the lessons learned from their lives. Hagiographies reflect on the sacred significance of individuals' everyday experiences, pain, and symbolic illness. . . Rather than being faithful to one chronological account, hagiographies are outside of normative histories and more marvelous than they are true to material facts" (Encarnación: Illness and Body Politics in Chicana Feminist Literature [New York: Fordham University Press, 2010], 54).

${ }^{22}$ Patricia Cox Miller, "Visceral Seeing: The Holy Body in Late Ancient Christianity," Journal of Early Christian Studies 12, no. 4 (2004): 392.

${ }^{23}$ Ibid., 398.

${ }^{24}$ Ibid., 399.

${ }^{25}$ Lugones, "Heterosexualism and the Colonial/Modern Gender System."

${ }^{26}$ Most discussions of the body in contemporary theology have focused on sexuality and in the recovery of eroticism. Although this is a crucial aspect of body theology — and has been central to Latina theory - the attention to bodies exclusively as sources of pleasure leads to romanticized views of embodiment.

${ }^{27}$ Althaus-Reid, "El Tocado (Le Toucher)."

${ }^{28}$ My discussion of Luz María Umpierre's work is based on Lázaro Lima’s insightful reading of her poetry (The Latino Body, 130-39). 
${ }^{29}$ Ibid., 138.

${ }^{30}$ The sea as symbol of fluid, rhythmic connection is a recurrent image in Caribbean philosophy, richly developed in Antonio Benitez Rojo's La isla que se repite: el Caribe y la perspectiva posmoderna and Édouard Glissant's Poetics of Relation.

${ }^{31}$ Many of these theorists, myself included, move between zones dominated by the nationalisms of their countries of origin and by the racial ideologies of the United States. Thus rather than using the idea of exile literally, I use it mainly to indicate the experience of living in a place where one's body is read as a foreign body-regardless of political status.

${ }^{32}$ Frantz Fanon, Black Skin, White Masks (New York: Grove Press, 1967), 109_ 40.

${ }^{33}$ Richard Rodriguez, Brown: The New Discovery of America (New York: Viking, 2002).

${ }^{34}$ Ibid., 15.

35 Cherríe L. Moraga, "It Got Her Over," in Cherríe L. Moraga, Loving in the War Years: Lo que Nunca Pasó por sus Labios (Cambridge, Mass.: South End Press, 2000), 64 .

${ }^{36}$ Linda Martín Alcoff, Visible Identities: Race, Gender, and the Self (New York: Oxford University Press, 2006), viii.

${ }^{37}$ Moraga, Loving in the War Years, 46. As Moya observes, "In her own articulation of a theory in the flesh, Moraga emphasizes the materiality of the body by conceptualizing 'flesh' as the site on or which the woman of color experiences the painful material effects of living in her particular social location" (Paula M. L. Moya, Learning from Experience: Minority Identities, Multicultural Struggles [Berkeley: University of California Press, 2002], 50).

${ }^{38}$ Rodriguez, Brown, 228.

${ }^{39}$ Gloria Anzaldúa, Borderlands/La Frontera: The New Mestiza (San Francisco: Aunt Lute Books, 1999), 104.

${ }^{40}$ Ibid. "But it is difficult to differentiate between what is inherited, what is acquired, what is imposed."

${ }^{41}$ Some Latina/o thinkers attempt to stabilize the meanings of visible identities by splitting race from ethnicity, assuming either that (1) race is inherited and ethnicity is acquired or (2) race is visible and unavoidable and ethnicity implies choice. Such distinctions are implicit in claims such as "I am a woman of color who is racially white." Although this helps foreground the differences between subjective agency and socially imposed limits, I wonder if such distinctions unwittingly reproduce the myths of race as nature. Do such distinctions in effect split body and culture, reducing corporeal inheritance to a limited set of recognizable features - most often skin color-thus occluding the cultural arbitrariness of racial categories? A similar problem has affected the distinction between sex and gender, a split that may lead to assume that sex is natural and gender is socially constructed.

\footnotetext{
${ }^{42}$ Rodriguez, Brown, 133.

${ }^{43}$ Ibid.
} 
${ }^{44}$ For a discussion of the parallel projections of "guilty imagination" onto black bodies see Dwight N. Hopkins, "The Construction of the Black Male Body," in Loving the Body: Black Religious Studies and the Erotic, ed. Anthony B. Pinn and Dwight N. Hopkins (New York: Palgrave Macmillan, 2004).

${ }^{45}$ Rodriguez, Brown, xi.

46 "To be fully human necessitated my claiming the race of my mother. My brother's sex was white. Mine, brown” (Moraga, Loving in the War Years, 90).

${ }^{47}$ Moya, Learning from Experience, 24.

${ }^{48}$ Yvonne Yarbro-Bejarano, The Wounded Heart: Writing of Cherrie Moraga (Austin: University of Texas Press, 2001), 92.

${ }^{49}$ Haraway, cited in Sandoval, Methodology of the Oppressed, 171.

${ }^{50} \mathrm{I}$ am focusing here on the challenges of these theories for Christian conceptions of Spirit, rather than offering a survey of Latinas' allusions to spirit—which would require a more extensive exposition than this project allows for.

${ }^{51}$ Ivone Gebara, Longing for Running Waters: Ecofeminism and Liberation (Minneapolis: Fortress Press, 1999), 184.

${ }^{52}$ The continuity between matter and energy in postmodern science may be an apt metaphor for rethinking the relationship between spirit and flesh. Perhaps flesh is a particular material form of the spirit?

${ }^{53}$ For a reading of spirit as a figure of memory see my "Ghostly Encounters: Spirits, Memory, and the Holy Ghost," in Planetary Loves: Gayatri Spivak,

Postcoloniality, and Theology, ed. Stephen D. Moore and Mayra Rivera (New York: Fordham University Press, 2010). For a discussion of the relevance of ghostly images in sociology see, Avery F. Gordon, Ghostly Matters: Haunting and the Sociological Imagination (Minneapolis: University of Minnesota Press, 1997).

${ }^{54}$ Anzaldúa, Borderlands/La Frontera, 104.

${ }^{55}$ Pérez, Chicana Art, 6.

${ }^{56}$ Ibid.

${ }^{57}$ Ibid., 306. 